\title{
Why Do Firms Imitate Each Other?
}

\author{
Marvin B. Lieberman \\ The Anderson School at UCLA \\ Box 951481 \\ Los Angeles, CA 90095-1481 \\ E-mail: marvin.lieberman@anderson.ucla.edu \\ Phone: (310) 206-7665 \\ Shigeru Asaba \\ Gakushuin University \\ Department of Economics \\ 1-5-1 Mejiro Toshima-ku \\ Tokyo, 171-8588 JAPAN \\ E-mail: shigeru.asaba@gakushuin.ac.jp \\ Phone: 011-81-3-5992-3649
}

July 24, 2004

We thank Joel Baum, Sushil Bikhchandani, David Hirshleifer, Charlotte Ren, Anand Swaminathan, Tatsuo Ushijima, Lynne Zucker and anonymous referees for valuable insights and suggestions. We remain responsible for all errors and omissions. 


\title{
Why Do Firms Imitate Each Other?
}

\author{
ABSTRACT \\ Scholars from diverse disciplines have proposed numerous theories of business imitation. \\ This paper organizes these theories into two broad categories: (1) information-based theories, \\ where firms follow others that are perceived as having superior information, and (2) rivalry- \\ based theories, where firms imitate others to maintain competitive parity or limit rivalry. We \\ describe conditions under which each type of imitation is most likely and offer guidance on \\ identifying imitation in practice. Amplification effects and other performance implications of \\ imitation are also addressed.
}




\section{Why Do Firms Imitate Each Other?}

Imitation is a common form of behavior that arises in a variety of business domains. Firms imitate each other in the introduction of new products and processes, in the adoption of managerial methods and organizational forms, and in market entry and the timing of investment. Despite its frequent occurrence, imitation can have radically different causes and implications. Firms may imitate to avoid falling behind their rivals, or because they believe that others' actions convey information. The matching of rivals' actions can intensify competition, or have the opposite effect by promoting collusion. Imitation can spur productive innovation, or amplify the errors of early movers. Thus, imitation can lead to large positive or negative outcomes for individual firms and society as a whole. Given the frequency of imitative behavior and the fact that societal outcomes are often negative, it is important that business researchers, managers and policy makers understand why imitation occurs and when it may have harmful implications.

Business scholars from a range of disciplines have proposed numerous theories of imitation. While these theories share common elements, they have been developed for specialized audiences and tend to emphasize different mimetic phenomena. Thus, the large body of research on imitation processes remains fragmented, with few scholars aware of related work by colleagues in other disciplines. The primary aim of this paper is to help develop this body of theory by drawing together common threads. 
Arguably, imitation processes are most interesting in environments characterized by uncertainty or ambiguity. Few decisions have outcomes that are fully predictable. Managers take actions whose consequences depend upon the future state of the environment. (In the case of a new product introduction, for example, such a state would correspond to a particular level of production cost, customer demand, degree of competition, etc.). At a minimum, most decisions are made under conditions of risk, where the probabilities of environmental states can be estimated, but the actual outcome is uncertain (Knight, 1921). Managers often face more severe forms of uncertainty: they may be unable to assign probabilities; they may lack information on cause-effect relationships; and they may be unable to assess the full range of possible outcomes and states (Milliken, 1987).

In this survey we emphasize the role of environmental uncertainty, which makes it difficult for managers to predict the consequences of a particular action or behavior. Environmental uncertainty promotes certain types of imitation and raises the likelihood of undesirable outcomes. In situations where the imitated behavior is tacit or complex, there may be additional uncertainty about the methods used by a leading firm to achieve superior results. This second type of uncertainty or "causal ambiguity" impedes the process of imitation, as we discuss briefly below.

Imitation of superior products, processes and managerial systems is widely recognized as a fundamental part of the competitive process. Many studies have documented processes of “creative destruction” (Schumpeter, 1942) and “diffusion of innovations” (e.g., Rogers, 1995) that lead to widespread adoption of superior products or methods. A related literature on "first mover advantages” (e.g., Lieberman and Montgomery, 1988) shows that successful pioneers seldom can prevent entry by imitative followers. Such imitation tends to reduce the innovator's profits while generating broader gains in economic welfare as prices and costs fall. Furthermore, 
it is widely recognized that when network externalities give rise to standards, firms imitate to minimize costs (Katz and Shapiro, 1985). In the absence of uncertainty, such types of imitation are comparatively straightforward and well understood.

In highly uncertain environments, however, imitative behavior can be dysfunctional or even pathological. Herd behavior can lead to speculative bubbles and the waste of resources in duplicative investments. Recent examples abound in the Internet sector, where a financial bubble in the late 1990s left in its wake a business landscape overpopulated by imitative startups and organizational forms. Dozens of Internet "business-to-business exchanges" sprouted before deficiencies of the format became apparent, and consulting firms rushed to set up enterprise "incubators," which were perceived during the boom as a superior new organizational form. As these examples suggest, imitation often provokes excessive investment, focused too narrowly on a limited number of options, with poor profit outcomes for the majority of firms. As Internet commerce burgeoned, many managers believed that they were adopting superior methods and systems, only to discover that they had followed others down largely fruitless paths. Imitation is a natural response to environmental uncertainty, but by reducing variety it can compound the collective risk of firms in an industry.

In environments where change is more incremental, imitation can defuse rivalry and reduce risk for any given firm. Knowledge that rivals will respond in kind lowers the incentive for any individual firm to act aggressively in an effort to gain competitive advantage. In the extreme, such imitation can be anticompetitive. Government antitrust authorities recognize this possibility and have overturned business agreements that promote parallel behavior. One example is the so called "smog case" where the "Big-Three" automakers agreed to share pollution control technology adopted by any one of the firms. The U.S. Justice Department 
alleged that by facilitating imitation, the agreement led the companies to cut back on $R \& D$ (White, 1971).

When competitors take similar actions, there is less chance that any firm will succeed or fail relative to others. Thus, imitation helps to preserve the status quo among competitors that follow each other, even in industries where strong rivalry is maintained. One example is Casio and Sharp, the leaders in electronic calculators, which repeatedly matched each other's incremental innovations in the 1970s. Their market shares remained balanced even though the lead shifted back and forth, and ultimately the two firms emerged with nearly identical product lines (Numagami et al., 1992). Moreover, by strengthening each other, these two Japanese producers were able to drive many foreign rivals from the global market. In this case, imitation stabilized the relative positions of the leaders while raising the risk of failure for those that did not follow.

As these examples suggest, imitation can occur for a variety of reasons with dramatically different implications. Under some conditions, imitation is apt to be beneficial and should be promoted. But in other settings imitation is more likely to have negative implications for firms and/or society. It is therefore important to distinguish among types of mimetic behavior and understand the potential consequences. To aid these assessments, this paper reviews a range of relevant theories in strategic management, economics, and organization theory. These disciplines have addressed the phenomenon of imitation from complementary perspectives.

Throughout the paper, we argue that all forms of imitation have some rational basis. Thus, we reject the view of some organization scholars that imitation is a purely ritualistic phenomenon. We recognize, however, that imitative behavior can often appear irrational, particularly when viewed in retrospect after uncertainty has been resolved. 
We organize theories of business imitation into two broad categories: (1) informationbased theories, where firms follow others that are perceived (sometimes erroneously) as having superior information, and (2) rivalry-based theories, where firms imitate others to maintain competitive parity or limit rivalry. The next two sections of this paper describe the informationand rivalry-based theories, respectively. We then address more applied problems of identifying these two types of imitation. The task is made difficult by the fact that the two types of imitation can arise simultaneously, and both types can be hard to distinguish from the non-imitative case where firms respond independently but identically to the same external shock. Final sections of the paper consider performance implications of imitation and opportunities for future research.

We do not review the empirical literature on business imitation in great detail, as our objective is to provide a conceptual survey rather than a discussion of specific findings. To give a broader guide to this literature, however, Table 1 lists some prominent empirical studies and their main conclusions.

\section{INFORMATION-BASED THEORIES OF IMITATION}

Information-based theories of imitation have been proposed in the fields of economics, institutional sociology and population ecology. These theories apply in environments where managers cannot assess connections between actions and outcomes with great confidence. Managers may be unsure of the likelihood of possible outcomes, and they may have more fundamental difficulties recognizing cause-effect relationships and the full range of potential consequences. In such environments of uncertainty and ambiguity, managers are particularly likely to be receptive to information implicit in the actions of others. Such information, while highly imperfect, can have a strong influence on managerial perceptions and beliefs. Moreover, 
in uncertain environments managers may imitate to signal others about their own (or their firm's) quality.

\section{Economic Theories}

We begin by considering economic theories of imitation, where the information component has been developed most explicitly. ${ }^{1}$ The most prominent economic theory of herd behavior is called information cascades or social learning (Banerjee, 1992; Bikhchandani, Hirshleifer \& Welch, 1992, 1998). Information cascades occur "when it is optimal for an individual, having observed the actions of those ahead of him, to follow the behavior of the preceding individual without regard to his own information” (Bikhchandani et al., 1992). The model formalizes a process of Bayesian learning. Suppose each agent has some private information about the state of nature. The first agent behaves purely based on this private information, but the agent's behavior reveals the information to followers. As this revealed information accumulates, it may be rational for followers to ignore their own prior information and mimic the decisions of others. A typical example is a restaurant with a long queue that becomes increasingly popular. Many of those waiting at the end of the line may have intended to visit other restaurants with which they are familiar, but they are swayed by the observation of the queue, which suggests (perhaps erroneously) that the restaurant is of high quality. Thus, agents

may choose to go against their initial signals as they draw inferences from the observed behavior of others.

Such processes have some power to explain the imitative behavior that contributed to the Internet bubble that began to rise in the late 1990s. Consider an entrepreneur contemplating a new retail venture, with an initial preference for "brick and mortar" outlets rather than Internetbased sales. Observing the growing wave of entry into the Internet sector (supported by the 
enthusiastic forecasts of analysts, the trade press, and rising stock prices) the entrepreneur concludes that perhaps others have superior information about the prospects for Internet retailing. Eventually, the observed signals grow in strength relative to the entrepreneur's prior belief, and the entrepreneur decides to follow others and enter the Internet sector. Similarly, financial investors initially skeptical of Internet commerce may have been swayed by the "information" revealed by the rising stock market, the trade press, and other sources. Such forces helped drive the Internet bubble upward.

As more entrepreneurs and investors are persuaded by such observations, the wave of entrants grows. But as Bikhchandani et al. (1992) point out, such processes are inherently fragile and subject to reversal. Just as a critical mass of positive actions is needed to start the cascade upward, if a sufficient number of negative signals emerge, the process will reverse. This may characterize the collapse of the Internet bubble in mid-2000, as pessimistic assessments began to appear and grew rapidly. Internet stock prices fell to a fraction of their previous levels and entry came to a virtual halt. The dramatic rise and fall took place within the span of just two or three years, much faster than the rate at which concrete data emerged on the long-term prospects for Internet commerce.

In driving such a bandwagon, the actions of some individuals or firms may be weighted more strongly than others. If some are perceived as likely to have superior information, they can become "fashion leaders" (Bikhchandani, et al., 1998). For example, small firms may follow larger rivals if they believe the latter to be better informed. Similarly, firms that have been successful in the past are more likely to have their actions emulated. In the case of Internet retailing, the entry of prominent firms such as Barnes \& Noble and Wal-Mart, and the enormous stock price gains of Amazon, helped legitimize the efforts of other retailers to quickly establish a 
presence on the Web. Such a role for leading firms is elaborated in the sociological theory of institutional isomorphism, discussed below.

A second economic theory of herd behavior is based upon the idea that managers ignore their own private information and imitate the decisions of others in an effort to avoid a negative reputation. By imitating, managers send signals to others about their own quality. Suppose that there are superior and inferior managers who have private information about investment. Outsiders do not know the type of each manager, but only that superior managers receive informative signals about the value of the investment while inferior managers receive purely noisy signals. Since the signals superior managers received might be misleading, outsiders cannot rely solely on the outcome of the investment, but also on behavioral similarity among managers. Therefore, in order to be evaluated as a superior type, managers ignore their own information and imitate others (Palley, 1995; Scharfstein \& Stein, 1990). Such imitation serves to enhance the manager's "status," a point elaborated in the institutional theories discussed below. This theory may help to explain the herd behavior of analysts and institutional investors in driving the Internet bubble upward. Financial actors are often evaluated on performance relative to peers; those who deviate from the consensus and ultimately prove to be wrong are likely to suffer a fatal loss of reputation. During the rise of the bubble it was widely believed that the leading Internet analysts had superior signals, which led them to be optimistic about the future of many Internet companies. Those who did not follow were often shunned for their failure to grasp the fundamental dimensions of the "new economy.” Under these circumstances, less-informed analysts and investors often chose to join with the crowd, pushing Internet stock prices higher. ${ }^{2}$ This example shows how the second economic theory of herd behavior can complement the first: information cascades likely contributed to the emergence of the trend, which was further sustained by reputation-based signaling on the part of analysts and investors. 


\section{Theories of Organizational Sociology and Ecology}

Organization theory gives a related explanation for behavioral similarity: institutional isomorphism. DiMaggio and Powell (1983) argue that rational actors make their organizations increasingly similar when they try to change them. This process of homogenization is captured by the concept of isomorphism. Isomorphism is a constraining process that forces one unit in a population to resemble other units that face the same set of environmental conditions (Hawley, 1986).

Among several kinds of institutional isomorphism, mimetic isomorphism is the process whereby organizations model themselves on other organizations when the environment is uncertain. The modeled organization is perceived as more legitimate or successful. Such mimetic behavior is rational because it economizes on search costs to reduce the uncertainty that organizations are facing (Cyert \& March, 1963). Empirical studies show the operation of mimetic isomorphism in a variety of organizational domains. For example, Fligstein (1985) applied the concept to explain the widespread adoption of the multidivisional structure; Haveman (1993) assessed the parallel diversification patterns of California savings and loan associations; and Greve (1995, 1996) considered format changes of radio stations.

Mimetic isomorphism can be viewed as rational imitation of a superior organization, although sociologists often emphasize ritualistic rather than rational motivations. For example, DiMaggio and Powell (1983) claim that the rapid proliferation of quality circles in American firms that modeled Japanese and European successes was intended to enhance the legitimacy of the adopting firm. March (1981) argues that once enough social actors adopt a certain behavior, the behavior is taken for granted or institutionalized, and thereafter, other social actors will adopt the behavior without thinking. Institutionalization can be viewed as a threshold effect that occurs once a critical mass of firms have adopted. In this sense it bears resemblance to the 
information cascades theory.

The sociological theory differs from information cascades in that once a behavior is institutionalized, organizations are slow to respond to new information. Behavior is much more durable than in the economic theory where new information can lead to sudden reversals. Information cascades can be fragile, whereas the sociological theory points to the emergence of a permanent social order. Another difference is that the sociological theory has generally been applied to explain the adoption of organizational processes and innovations, whereas the economic theory aims to be more general. ${ }^{3}$

While the economic theory of information cascades recognizes the potential of "fashion leaders," it has been the organizational sociologists who have actually probed the issue of "who imitates whom.” Sociological studies indicate that a given firm’s propensity to be imitated increases with: (1) the information content of its signal (where actions by larger, more successful, or more prestigious firms may be seen as more informative) and (2) the focal firm's degree of contact and communication with other firms. Many studies have shown that organizations of larger size and profitability are more likely to be followed (e.g., Haunschild \& Miner, 1997; Haveman, 1993). Moreover, theories of social networks (Granovetter, 1985; Gulati, Nohria \& Zaheer, 2000) suggest that when organizations are linked by greater network ties they are likely to have more detailed information about each other, which facilitates imitation. Along these lines, Davis (1991) and Haunschild (1993) found that imitation was more likely between firms with interlocking directors, and Greve (1996) found that radio stations were more likely to follow other stations that were units of the same corporation. Simulations by Abrahamson and Rosenkopf (1997) show how seemingly minor network structural features can affect the diffusion process.

These firm and network characteristics are seldom independent. Organizations that are 
central in a network have links with the greatest number of others; such organizations also tend to be larger and more prestigious. As Gulati and Gargiulo (1999: 1448) point out, "the more central an organization's network position, the more likely it is to have better information.”

While the above discussion emphasizes rational interpretation of signals, studies flowing from the work of DiMaggio and Powell (1983) show that early and late movers may differ in their motivations (e.g., Fligstein, 1985, 1991; Westphal, Gulati and Shortell, 1997). This work suggests that early movers tend to be rational, whereas late movers are often engaged in symbolic action and are merely seeking status. Such followers are not concerned about interpreting the signals of others; rather, by copying more prestigious firms they seek to send a signal about their own legitimacy. Viewed in the context of the reputation-based theory of economics, such efforts can be seen to enhance the firm's relations with resource providers if the environment is sufficiently uncertain. For instance, followers that entered Internet markets during the rise of the bubble were often able to raise large amounts of capital despite imitative strategies that later proved highly flawed. Thus, status-seeking imitation can benefit the firm and its owners, even if the imitated action is not in the firm's best interest per se. In this sense, status-seeking imitation can be rational behavior.

"Legitimation" is another concept of organization theory that is related to the cascade theories of economics. Scholars of organizational ecology have long noted that once a new industry has acquired a threshold number of entrants, the firms acquire a legitimacy that facilitates their growth (Carroll \& Hannan, 1995; Hannan \& Carroll, 1992). Banks, for example, become more willing to supply capital, and potential employees can be more easily hired. This expansion in the availability of resources, in turn, often leads to a further wave of entry. Thus, there is a threshold effect in entry processes, similar to the economist's notion of an information cascade. One difference from the economic theory is that growth in the number of entrants 
increases legitimacy while also making competition more intense. The offsetting force of competition places a ceiling on the equilibrium number of firms. Limits of this sort are not normally considered in the economic theory.

\section{Interactions Between Mimetic and Experiential Learning}

The information-based theories describe processes where organizations learn by drawing inferences from the behavior of others. Other forms of learning occur in an industry as more detailed information emerges from the experience of early movers, and as organizations assess their own experience (Baum, Li \& Usher, 2000; Haunschild \& Miner, 1997). Whether firms emphasize one mode of learning over another depends upon their resources and the time they can wait before committing to a decision. Experience (or experiment) is more costly and timeconsuming than imitation, which can be viewed as a form of satisficing (Baum, et al., 2000; Cyert \& March, 1963; March, \& Simon, 1958). When firms have adequate time and resources to extensively explore their environment, experiential learning will be preferred. But in highly uncertain environments where quick action is necessary, to imitate others becomes an attractive decision rule. Such a rule appeals most to those with little prior information on which to base a decision; more knowledgeable firms may rely on what they know internally.

Typically, firms draw upon some combination of these learning processes. In his studies of format choice by radio stations, Greve (1996) found that stations were influenced by the choices of other units within their corporation (reflecting a process of organizational learning), as well as by the choices of independent stations in the geographic area. Studies of international entry decisions show that imitation may influence the firm's initial decision to enter a county, after which it learns from its own and others' experience in that country (e.g., Shaver, Mitchell \& Yeung, 1997). 
As a new industry or commercial area evolves, mimetic, vicarious and experiential learning proceed together, often with smaller firms mimicking the behavior of larger rivals, as the latter gain information through investments in marketing and R\&D. Firms may shift from external to internal information sources as they build capabilities in a given area. Stuart (1998), for example, found that large semiconductor firms enter fewer research and development alliances as they develop better in-house capabilities over time.

Time lags and relative learning rates affect the dynamics of imitation and the likelihood of inferior outcomes. If firms perceive a need to act early in an environment where experiential learning is slow, mimetic processes can yield behaviors that are durable even though they may ultimately prove to be highly sub-optimal. On the other hand, if experiential learning is fast, or if firms are able to wait until outcomes are clear, the experience of early movers will resolve many uncertainties and allow followers to converge on good choices.

Followers can sometimes invest in “absorptive capacity” (Cohen and Levinthal, 1990) to facilitate learning from others and speed implementation. Followers with strong absorptive capacity may be able to delay commitment and collect better information without compromising their ability to respond. Absorptive capacity extends the window for effective action, reducing the risk that the firm imitates too early or too late, and allowing for better decisions on whether to imitate at all.

In a simulation model of innovation adoption, Rosenkopf and Abrahamson (1999) explore the interactions between imitation, uncertainty and lagged learning. In their model, the profitability of early adopters is transmitted to the remaining firms after a lag; followers place greater weight on this information when "uncertainty" is low. The simulations show that the longer the learning lag, the more cycles during which an imitative bandwagon can build before it is potentially halted by information that the innovation is not profitable. Interestingly, the effects 
of the learning lag on imitation are greatest under conditions of moderate uncertainty. When uncertainty is low, most firms simply wait to learn whether the innovation is profitable; when uncertainty is high, the information on profitability is deemed unreliable, and hence it lacks sufficient weight to cut off the imitative bandwagon. While the model shows how lagged learning can slow down or stop a growing bandwagon, the more extreme dynamics of reversals, predicted by the information cascades theory, are ruled out in the model by assumption.

Bikchandani et al. (1992) make the point that information cascades fail to provide “deep” learning; after the start of the cascade the actions of followers provide no additional information, since it is recognized that they are simply responding to the information revealed by the initial actors. Given this shallowness of beliefs, only a small amount of independent learning is needed to overturn the cascade if the imitated behavior proves erroneous. Subsequently, a new cascade may arise once a sufficient number of firms discover a superior alternative. For example, one might view the continual progression of management "fads” (e.g., "total quality management,” “re-engineering," “employee empowerment,” etc.) as proceeding roughly in this manner, as firms imitate organizations that they believe to be better informed but discover through experience the limits of the new managerial system. Such reversals are not emphasized in the organizational theories, which take the mimetic behavior as more durable. [Abrahamson's (1991, 1996) work on management fads is a notable exception.] One reason for the difference in emphasis is that the sociological studies focus on adoption of organizational innovations for which information lags are typically long and residual uncertainty high. In many other domains where imitation occurs, uncertainty is resolved more quickly or completely. This makes reversals more likely and may prevent the imitation entirely if firms wait to learn from the experience of early movers. 


\section{THEORIES RELATING TO COMPETITIVE RIVALRY AND RISK}

A second set of theories regards imitation as a response designed to mitigate competitive rivalry or risk. Firms imitate others in an effort to maintain their relative position or to neutralize the aggressive actions of rivals. Unlike the theories discussed in the previous section, firms' actions do not convey information. The theories relating to rivalry and risk have their primary origin in the fields of economics and business strategy.

Imitation to mitigate rivalry is most common when firms with comparable resource endowments and market positions face each other. Competition can be very intense in such cases, with prices and profits eroded easily (Peteraf, 1993). To alleviate this situation, firms can pursue either differentiation or homogeneous strategies (Baum \& Haveman, 1997; Deephouse, 1999; Gimeno \& Chen, 1998). Firms that differentiate their resources and market position from

those of competitors become insulated from the actions of rivals. This reduces the likelihood of imitation and leads to higher profits if the differentiated position proves sufficiently attractive. Pursuing a differentiation strategy is, however, often difficult and risky. The firm cannot be certain that the new position or niche will be superior. Faced with a choice, firms therefore often choose to pursue homogeneous strategies, where they match the behavior of rivals in an effort to ease the intensity of competition or reduce risk.

\section{Homogeneous Strategies to Mitigate Rivalry}

When resource homogeneity creates a potential for intense competition, matching behavior may be a way to enforce tacit collusion among rivals. Studies of repeated games show how “tit for tat” strategies can punish deviant behavior and thereby maintain cooperation (Axelrod, 1984). In his early work on strategic groups, Porter, (1979: 217) suggested that firms within the same group behave similarly because "divergent strategies reduce the ability of the 
oligopolists to coordinate their actions tacitly ... reducing average industry profitability.” In other words, firms within the same strategic group may adopt similar behavior to constrain competition and maintain tacit collusion. ${ }^{4}$ More recent work in strategy and economics gives similar predictions. Studies on action-response dyads (Chen \& MacMillan, 1992; Chen, Smith \& Grimm, 1992) suggest that matching a competitor's move indicates a commitment to defend the status quo, neither giving up the current position nor falling into mutually destructive warfare. Similarly, Klemperer (1992) shows that competitors may duplicate their product lines to mitigate rivalry. If firms offer identical product ranges, each consumer can avoid the costs of dealing with multiple firms by selecting a single supplier. This segmentation of customers may make the market less competitive.

The hypothesis that firms adopt similar behavior to mitigate rivalry can be also derived from studies on multimarket contact (Bernheim \& Whinston, 1990; Karnani \& Wernerfelt, 1985; Leahy \& Pavelin, 2003). Edwards (1955) was the first to argue that multimarket contact might blunt the edge of competition, because "A prospect of advantage from vigorous competition in one market may be weighed against the danger of retaliatory forays by the competitor in other markets." 5 When firms compete with each other in many markets, they can more easily sustain collusion, because deviations in one market can be met by aggressive responses in many places. This is the idea of "mutual forbearance.” ${ }^{6}$ The multimarket contact theories suggest two ways that competitors may imitate: (1) they may respond to a rival's aggressive move in one market with a similar move in another market; (2) they may match rivals' entry decisions in order to increase the degree of multimarket contact. 


\section{Risk Minimization}

Other researchers have proposed that imitation stems from the desire of rivals to maintain relative competitive position. One of the first documented examples was the "bunching” of foreign direct investment (FDI), as rivals matched each other's entries into foreign markets. Knickerbocker (1973) argued that such “follow-the-leader” behavior is the result of risk minimization. If rivals match each other, none become better or worse off relative to each other. This strategy guarantees that their competitive capabilities remain roughly in balance. Motta (1994) gives a game theoretic explanation for this follow-the-leader behavior, and Head, Mayer \& Ries (2002) show that it can be sustained only when managers are risk averse. Table 1 lists many empirical studies that provide evidence on the existence of "follow-the-leader" behavior in foreign market entry (e.g., Knickerbocker, 1973; Flowers, 1976; Caves et al., 1980; Yu \& Ito, 1988; Yamawaki, 1998). Other studies in the strategic group literature (e.g., Fiegenbaum \& Thomas, 1995; Garcia-Pont \& Nohria, 2002) show that firms are likely to imitate other group members in an effort to maintain competitive parity.

In domains such as FDI and other types of entry, the incentives for imitation should diminish as more firms follow and intensify competition within the market niche. Thus, there may be a self-limiting dynamic to some rivalry-based imitation, as in the population ecology theories discussed previously. Supporting this idea, Martin, Swaminathan \& Mitchell (1998) found the likelihood that a given Japanese automotive supplier would enter the North American market rose and then fell with the number of competing suppliers that had already entered. In domains where this offsetting force of competition is lacking (e.g., imitation of organizational structures), imitation can be more widespread.

In “winner takes all” environments, rival firms may adopt similar behavior to prevent others from leading the race. For example, in R\&D competition, where the first inventor can 
obtain patent rights to a technology so that other firms cannot use it, R\&D investments among firms are positively correlated. Such competition leads to over-investment (Dasgupta \& Stigliz, 1980). ${ }^{7}$ Similar “winner takes all” situations can arise when the market has bandwagon effects or network externalities (Leibenstein, 1950; Katz \& Shapiro, 1985).

\section{DISTINGUISHING AMONG IMITATION PROCESSES}

The information- and rivalry-based theories described above are not mutually exclusive; both types of imitation can occur simultaneously. Firms may imitate rivals to maintain competitive parity and also out of belief that rivals may possess superior information. Nevertheless, one type of imitation or the other is apt to be predominant in any given context. In this section we draw some predictions about the conditions under which each type of imitation is most likely. These distinctions provide guidance for researchers and managers in attempting to identify mimetic behavior and assess the potential consequences of imitation. In addition, we consider the problem of distinguishing imitation from other types of isomorphism, including the basic case where firms respond independently but identically to a common environmental shock.

\section{Using Environmental Conditions to Distinguish Among Theories}

Empirical researchers have often sought to find evidence of imitation, taking one specific theory or type of imitation as given. For example, many studies in the international business literature find evidence on the bunching of entry by foreign firms as the assumed consequence of interfirm rivalry. Other researchers in organizational ecology have commonly found a surge of entry once a new industry achieves “legitimacy” (c.f., Carroll \& Hannan, 1995; Hannan \& Carroll, 1992). While these presumed mechanisms of imitation may be valid in their respective 
contexts, more work is needed to test alternative theories and link theories to the environmental conditions where they are most applicable.

The flow chart in Figure 1 applies three criteria to help distinguish between informationbased and rivalry-based imitation. The first two criteria, market overlap and resource similarity, establish whether the leader(s) and follower compete as rivals. Rivals have strong overlap in product lines and geographic market coverage. Often they have similar resources, and they may share similar origins and history.

If the firms are not rivals, the follower can be judged to have information-based motives for imitation. In general, information-based motives are likely to be dominant when firms differ in market position, size, or resources, or when uncertainty is very high. Asymmetry limits rivalry and raises the likelihood that some firms possess superior information. High uncertainty implies that managers have weak "prior probabilities” about the likely success of alternative paths and are therefore more open to external sources of information. Furthermore, patterns may be observed—small firms following larger firms, or general imitation of successful firmssuggesting that the imitation process is information based.

If firms do compete as rivals, both types of imitation may coexist. Even so, the third criterion (degree of uncertainty) has some power to distinguish between the two motives for imitation. Rivalry-based motives are likely to dominate when the degree of uncertainty is low. Closely matched competitors often have similar information but strong rivalry. Multimarket contact (not incorporated in Figure 1) further increases the likelihood of rivalry-based imitation, as it expands the domains where imitation can occur and raises the probability that firms respond to each other in kind. Firms that are closely matched may also be risk averse, particularly to loss of market share, a condition that is necessary for some types of rivalry-based imitation.

Several empirical studies have applied such criteria to classify imitation processes. In a 
study of entry by U.S. telecommunications firms into foreign markets, Gimeno, et al. (2001) use differences in domestic market overlap to distinguish rivalry-based imitation. They find a clustering of foreign entries by firms that compete directly with each other in regional U.S. markets, but no such pattern for local-monopolist "Baby Bells." This suggests rivalry as the dominant motive for the bunching of foreign market entry, a conclusion consistent with the assumptions of prior FDI studies. Asaba and Lieberman (1999) use differences in uncertainty to distinguish imitation processes relating to new product introductions in the Japanese soft-drink industry. They find a tendency for larger firms to be followed in cases of major innovations where uncertainty is high, whereas close rivals are followed for incremental product changes. This supports the idea that information-based motives prevail under conditions of high uncertainty, but rivalry motives prevail when uncertainty is low. In a study of investment timing by chemical producers, Gilbert \& Lieberman (1987) find a pattern in which small firms mimic the capacity expansions of large firms, while the latter avoid imitating each other for fear of creating overcapacity. Such a pattern is consistent with information-based motives, where small producers draw upon on the superior ability of large firms to forecast growth in demand.

To be sure, Figure 1 does not provide a perfect guide to distinguish between information and rivalry motives. When firms are direct competitors the two sets of motives may be closely intertwined. Rivals that share common technology, organization, and market orientation may be particularly informative to each other. Even so, differences in the degree of environmental uncertainty provide some basis for judging the relative importance of the two motives. Among examples considered in this paper, the degree of uncertainty varies greatly. At one extreme, Internet commerce in the late 1990s was characterized by enormous uncertainty and ambiguity. In this environment, imitation was likely to have been mostly information-based, even for firms that competed with each other. By comparison, uncertainty was relatively low for incremental 
product enhancements in the calculator industry, where rivalry was likely the primary motive for imitation. Other examples where both motives for imitation seem to have been strong (e.g., Japanese FDI in North America) are intermediate between these extremes.

\section{Identical Responses to Common Environmental Shock}

We have argued that fundamental characteristics of the industry environment and the identity of initiating firms provide a basis for distinguishing between information- and rivalrybased imitation processes. One complication is that both types of imitation may occur simultaneously, even though one is predominant. A further complication is that what looks like imitation may simply be firms’ independent responses to a common external stimulus.

As an example, consider an economic recession that induces many firms to lay off part of their workforce. Such layoff decisions are made primarily on the basis of forecasts of future sales. To the extent that firms are subject to the same demand fluctuations and have access to the same public information about macroeconomic conditions, one would expect them to make reasonably similar and simultaneous cutbacks. To regard such behavior as imitation would clearly be incorrect.

Some degree of imitation may nevertheless occur in such situations, stemming from information or rivalry motives (or both). For example, firms may look to the announcements of others as a source of information about the likely depth of the recession in their industry. Similarly, if rivals have not yet announced layoffs, a firm may be reluctant to act alone for fear that it could lose competitive position. In such instances, once one firm announces cutbacks, many others may follow suit.

Thus, we often observe the confluence of both imitative and non-imitative responses to external shocks. This simultaneity makes clear-cut identification of imitative behavior a thorny 
problem for empirical researchers attempting to characterize imitation processes. When data are available on many organizational units, the time lags associated with imitation provide a means to distinguish the two types of response. The diffusion framework of Strang and Tuma (1993), which provides the basis of recent applied work by organization researchers, allows one to separate independent responses to a shock (in the intrinsic propensity vector) from contagion effects (in the susceptibility, proximity and infectiousness vectors). Strang and Tuma's eventhistory method allows one to characterize contagion processes within a population of potential adopters. However, the method may be less useful for distinguishing imitation and related processes among small numbers of competitors within a market or niche. In general, economists have been much less sanguine than sociologists about the ability to carry out empirical research on social interactions (e.g., Manski, 2000).

\section{Resource and Complexity Constraints on Imitative Behavior}

Imitation processes are also influenced by resource constraints that limit the scope of firms' behavior. Firms with very different resource endowments may be unable to behave similarly even if they face the same environment. This is because strategy is constrained by the current level of resources, as many scholars of the resource-based view of the firm point out (e.g., Collis, 1991; Teece , Pisano \& Shuen, 1997). Firms may be able to mimic others only when their resource endowments are comparable. In the petroleum industry, for example, Helfat (1997) shows that synthetic fuels became an attractive opportunity when oil prices rose sharply in the 1970s, but only those firms with requisite expertise in petroleum refining R\&D were able to invest. Since firms with similar resources are often direct rivals, resource constraints can make it appear that rivals are responding to each other, even though their actions are independent responses to a common environmental shock (as in the case of synthetic fuels). 
Complexity serves as a further constraint on imitative behavior. Firms with adequate resources can easily copy simple actions but not complex repertoires containing many elements, particularly when tacit skills are involved. Causal ambiguity about which elements are most important leads to “uncertain imitability” (Lippman \& Rumelt, 1982). If many elements and their interactions must be duplicated to achieve success, the sheer burden of the task may prevent imitation (Rivkin, 2000). Applied studies by Szulanski (1996) and Ounjian \& Carne (1987) confirm that imitation is impeded by causal ambiguity and complexity.

\section{PERFORMANCE IMPLICATIONS}

Previous sections of this paper have described the amplification effects of imitation that make outcomes more extreme. Consequences may be good or bad for individual firms and for society. On the positive side, information-based imitation can speed the adoption of useful innovations, and rivalry-based imitation can spur firms to improve their products and services. Both types of imitation have negative implications if they lead firms to squander resources on wasteful, duplicative investments. Thus, the two modes of imitation can have similar effects, although there can also be important differences. We first address performance implications that apply to both types of imitation, followed by more specific implications of information and rivalry-based processes.

\section{Performance implications of both imitation types}

Imitation processes lead firms to converge on common choices more rapidly and in larger numbers than they would otherwise. The consequences, when beneficial, are reasonably straightforward, but when negative they are often dramatic. Industries may lock in to inferior choices or greatly overshoot the optimum level of investment. As discussed previously, 
imitation helped to promote the early boom-bust cycle of Internet commerce and numerous business fads. Imitative investments in optical fiber cables during the Internet boom led to a glut of telecommunications capacity, culminating in spectacular failures by Global Crossing and WorldCom—-the latter representing the largest corporate bankruptcy in history (Barreto and Baden-Fuller, 2002). Such examples suggest that dysfunctional imitation abounds, even though it is hard to document definitively.

If early movers have chosen a productive path, imitation accelerates the industry's convergence on a good solution. Imitation can help to promote network effects and common standards, with broad potential benefits for firms and consumers. In VCRs, for example, Japanese producers benefited from their early convergence on magnetic tape as the storage medium. Sony, the Japanese pioneer, had correctly recognized that tape was superior to alternatives being pursued in the 1970s, such as the videodisk developed by RCA. Sony's Japanese rivals focused their efforts on improving magnetic tape technology, the speedy development of which enabled Japanese manufacturers to dominate the global market (Rosenbloom \& Cusumano, 1987).

If the wrong path is chosen, however, imitation can be costly for firms and for society. In high-definition television (HDTV), the Japanese electronics firms adopted analog technology in the 1980s and heavily promoted its development. Eventually, it became clear that the analog approach was inferior to digital. Despite their dominance in many areas of consumer electronics, the Japanese firms found themselves at a serious disadvantage in world markets for HDTV. The growth of HDTV in Japan and elsewhere was hampered as a result.

The VCR and HDTV examples illustrate the fact that imitation raises the odds of extreme outcomes when the environment is uncertain. If the leaders have superior information and luck, imitation leads to quick convergence on superior choices and is socially beneficial. Rivalry and 
shared learning may stimulate firms and accelerate progress. On the other hand, if the path that is imitated proves inferior, imitation can create an industry-wide "competency trap” (Levitt \& March, 1988; Miner \& Haunschild, 1995). By comparison, when firms act independently they converge more slowly, but the diversity of approach avoids the worst industry outcomes and is collectively more robust.

Thus, by reducing variation in firms' strategies and technological paths, imitation raises the collective risk of an industry. When firms imitate each other in an uncertain environment they place identical bets on the future, thereby raising the odds of large positive or negative outcomes. As a result, society bears higher risk, even though individual firms may diminish their risk of falling behind rivals.

The propensity of firms to imitate may be culturally or socially influenced. Some societies may be more prone to imitation and as a result may show a wider range of performance variation across industries. For example, the tendency to copy rivals is often considered particularly strong in Japan (Asaba, 1999). Such tendencies may contribute to that nation's superior record of performance in some economic areas, but deep weaknesses in others.

Imitation tends to be socially beneficial—and potentially profitable—in situations where the imitators complement each other. Complementarities often arise in environments with network externalities or agglomeration economies. For example, Baum \& Haveman (1997) found that hoteliers tend to locate new hotels close to established hotels. Agglomeration of hotels attracts people, goods, and services, and consequently, it increases the attractiveness and reputation of the location. This is beneficial to society as well as to the hotels. At the same time, though, the close location of hotels can intensify price competition, making hotels less profitable. Thus, for imitating firms, the benefits of network effects, agglomeration economies and other positive externalities can be offset by pressure for price competition. 


\section{Information-based imitation}

While both types of imitation can have amplification effects, dramatic negative outcomes are more likely under information-based imitation. The information cascades theory is explicit about the potential for bubbles and sudden reversals. Other work in organization theory shows how lags in learning processes allow bandwagons to grow. The risk of inferior outcomes is greatest if managers perceive a need to commit before major uncertainties are resolved. In the rise of Internet commerce, for example, widespread belief in early mover advantages led to a rush of commercial efforts on the Web (Lieberman, 2002). Eventually, as more information emerged about the prospects for Internet businesses, stock prices collapsed and many firms failed. In retrospect, it is clear that much of the initial rush had been unnecessary and that it contributed to the magnitude of the collapse. Had more firms waited until major uncertainties resolved, many losses could have been avoided.

The speed with which uncertainty is resolved depends upon context. New products may succeed or fail within months, and key uncertainties surrounding new technologies are often resolved within a few years. Most organizational innovations, however, are characterized by longer gestation lags and more residual uncertainty. Consequently, one often observes dysfunctional imitation of organizational innovations, and the related phenomenon of managerial fads. Abrahamson (1991) suggests that many managers misunderstand the lag structure and abandon fads too quickly, following the next wave of imitation before most benefits of the prior wave have been realized.

Individual firms fail when they attempt to imitate a successful leader but prove incapable of doing so. Smaller firms may imitate in an effort to elevate their status or legitimacy, despite a lack of resources to do so successfully (Fligstein, 1985, 1991). Observation of the successful 
actions of others may raise aspiration levels beyond what can realistically be attained (Greve, 1998). Moreover, even large firms may imitate the superficial features of complex innovations while failing to replicate more subtle but essential elements. Thus, followers fail when they lack critical resources, or when complexity, tacitness and causal ambiguity prevent them from gaining a sufficient understanding of the innovations made by the target firm.

\section{Rivalry-based imitation}

The theories presented earlier suggest that rivalry-based imitation may serve to reduce the level of competition in an industry, or to increase it. Here again we have possibilities for diametrically opposite outcomes. For example, imitation may lead firms to cut back on R\&D, as in the "smog" case cited in the introduction, or to raise R\&D investment, as in the Japanese calculator and VCR examples. Theory offers some basis for predicting which outcome will prevail: collusion becomes more likely when firms have multimarket contact, whereas competition is promoted in winner take all environments. Empirical studies suggest that rivalrybased imitation generally raises the intensity of competition and lowers profitability (Barreto \& Baden-Fuller, 2002; Deephouse, 1999; Ghemawat, 1991; Odagiri, 1992). One conclusion is that intensification of competition is most common, but either type of response can arise depending on aspects of firm interaction and history that can be subtle and difficult to observe (Kreps \& Spence, 1985).

Such dichotomization between competition and collusion may, however, be too simple. Rivalry-based imitation often proceeds for many rounds where firms repeatedly match each other's moves. This process can strengthen firms that imitate at the expense of other rivals and is thus a form of the "red queen" effect discussed in the organizational literature (Barnett \& Hansen, 1996; Barnett \& Sorenson, 2002). Such imitation leads to differential performance among 
groups of firms and can create barriers to entry. If innovation is promoted and prices fall, the process is beneficial to consumers, but if only a few firms survive it can lead to an increase in market power.

The electronic calculator industry provides one example. Casio and Sharp responded to each other by introducing many new product features and cost reductions, leading to market growth and gains to consumers. Similarity of product and market position made each firm a good reference for the other, which facilitated learning. Ultimately, the accumulation of product enhancements enabled Casio and Sharp to drive out their American rivals who had pioneered the basic technology. Despite the losses to American producers, it seems likely that this process was socially beneficial.

A related example is Coke and Pepsi, which matched each other's advertising, promotion, and new product moves in the U.S. soft drink market over many decades (Moriguchi \& Lane, 1999). Challenging and learning from each other, the two rivals became progressively stronger, squeezing out smaller producers while maintaining high profitability. One feature of the soft drink industry is that it supports many dimensions of multimarket contact (over products, regions, etc.), which may have helped Coke and Pepsi to signal each other and prevent mutually destructive warfare.

\section{CONCLUSIONS AND IMPLICATIONS FOR FUTURE RESEARCH}

We have surveyed theories of business imitation and have shown that they fall into two broad categories: information-based theories and rivalry-based theories. The two types of imitation have different implications, although both have amplification properties that make outcomes more extreme. Information-based imitation can speed the adoption of superior 
products and methods, or it can lead to dramatic failures, as the Internet examples in this paper attest. Rivalry-based imitation can facilitate collusion, although more commonly it intensifies competition. In the latter case imitation often proceeds over many rounds, potentially strengthening firms if they have chosen a productive path, or leading them further astray if they have not.

We have suggested some ways that the two types of imitation can be identified and distinguished in empirical work. We have also pointed out that this is not an easy task. Several vexing problems make identification difficult: firms may respond identically (but not imitatively) to common environmental stimuli; the two types of imitation may coexist when firms are rivals; and key distinguishing characteristics (such as the "degree of environmental uncertainty”) may be hard to assess objectively. Identification of imitation processes therefore remains a challenge for those engaged in applied research.

Despite such difficulties, more research seems warranted, given the prevalence of business imitation and its potential consequences. This survey has reviewed studies from a range of academic disciplines. We see abundant opportunities for more cross-fertilization, particularly between economists and organizational scholars.

Economists have modeled information-based imitation in a stylized way that offers conceptual precision at the expense of recognizing the varied forms of learning that operate in practice. By comparison, studies from the perspective of organization theory offer a more comprehensive view of learning as well as insights about the role of communication networks in shaping the path of imitation. Organizations scholars have shown how network structure, concurrent learning processes, and information lags can have important effects on imitative outcomes. Such features might usefully be incorporated in economic models. Empirical studies of imitation by economists have been limited in quantity and narrow in 
scope. Historically, much of this literature focused on the bunching of foreign direct investment. More recently, economists have searched for effects of information cascades in financial markets (Bikhchandani and Sharma, 2001; Hirshleifer and Teoh, 2001). We see many opportunities for studies of imitation beyond the domains of financial markets and FDI. In terms of statistical tools, the event history models of organizational sociology may also be applicable in economicsoriented studies.

For organizational researchers, the precision of the economics approach is an attractive feature that can bring greater conceptual clarity to work on imitation. More explicit recognition should be made of the informational aspects of imitation. Indeed, we have argued that many insights of institutional theory can be viewed as signaling processes and rational responses to revealed information. We also see opportunities for more studies that explore interactions between mimetic and experiential forms of learning. Firms draw inferences from the observed behavior of others, from direct communication with others, and from their own experience-all three types of learning are important. Nevertheless, the literatures on imitation and organizational learning have evolved almost completely independently of each other. Realistic models of learning must incorporate and integrate these alternative modes of information acquisition.

Empirical studies of imitation in the organizations literature have mostly focused on the adoption of organizational innovations and practices (or market entry, in the case of studies within the subfield of population ecology). Researchers might consider a broader set of domains where imitation processes arise, including new product introductions, capacity expansion, R\&D, and other forms of business investment. At very least, it is important to recognize that the issues normally considered in the organizations literature are a subset of the business domains where imitation occurs. 
Finally, we suggest that all researchers take more explicit account of the costs and benefits of imitation. This study has highlighted the amplification properties that make outcomes more extreme. We have shown that imitation has many potential benefits: it speeds the adoption of innovations (beneficial if the innovation proves useful); it can intensify pressures for firms to improve their products; and it can promote network effects and other positive externalities and complementarities. On the negative side, imitation can lead to destructive competition, overinvestment, reduced variety and increased risk. In some situations imitation can support anticompetitive outcomes. From a policy perspective, it would be useful to have some rough accounting of the benefits and costs of imitation in specific contexts, as well as an assessment of ways to potentially mitigate the costs through market interventions or enhanced managerial sophistication. 


\section{ENDNOTES}

${ }^{1}$ The economic theories are an outgrowth of earlier work on how information affects the operation of markets, for which George Akerlof, Michael Spence and Joseph Stiglitz were awarded the 2001 Nobel Prize.

${ }^{2}$ In addition, many stock analysts had conflicts of interest that encouraged them to issue positive forecasts in order to promote their employer's relationships with client firms.

${ }^{3}$ Most sociological studies focus on adoption, but some, such as Davis, Diekmann and Tinsley (1994) and Greve (1995), consider the reverse process of deinstitutionalization.

${ }^{4}$ While strategic groups may be able to sustain tacit collusion in this way, firms within a strategic group typically experience more competition among their group members than with members of other strategic groups within the same industry (Greve, 1996).

${ }^{5}$ From Corwin Edwards' testimony quoted by Scherer (1980: 340).

${ }^{6}$ Empirical studies, however, often fail to support the mutual forbearance hypothesis (Heggestad \& Rhoades, 1978; Rhoades \& Heggestad, 1985; Scott, 1982). Bernheim \& Whinston (1990) and Karnani \& Wernerfelt (1985) suggest that the ambiguous empirical results of the existing studies are due to different effects of multimarket contact depending upon the characteristics of markets and firms. Controlling carefully for such characteristics, several recent empirical studies on multimarket contact support the mutual forbearance hypothesis (Evans \& Kessides, 1994; Gimeno \& Woo, 1996).

${ }^{7}$ In an empirical study of the pharmaceutical industry, Cockburn and Henderson (1994) find little evidence of the correlated R\&D responses predicted by economic theory. They suggest that "winner takes all” situations are rare; R\&D races typically yield multiple prizes. 


\section{REFERENCES}

Abrahamson, E., 1991. Managerial Fads and Fashions: The Diffusion and Rejection of Innovations. Academy of Management Review, 16: 586-612

Abrahamson, E., 1996. Management Fashion. Academy of Management Review, 21: 254-285.

Abrahamson, E. \& Rosenkopf, L., 1997. Social Network Effects on the Extent of Innovation Diffusion: A Computer Simulation. Organization Science, 8: 289-309.

Asaba, S., 1999. Behavioral Similarity among Japanese Firms. Doctoral dissertation, UCLA Anderson Graduate School of Management.

Asaba, S. \& Lieberman, M. B., 1999. Why Do Firms Behave Similarly? A Study on New Product Introductions in the Japanese Soft-drink Industry. Paper presented the August 1999 meeting of the Academy of Management (in proceedings), Chicago, IL.

Axelrod, R., 1984. The Evolution of Cooperation. New York: Basic Books.

Banerjee, A. V., 1992. A Simple Model of Herd Behavior. Quarterly Journal of Economics, 107: 797-817.

Barnett, W. P.,1993. Strategic Deterrence Among Multipoint Competitors. Industrial and Corporate Change, 2(2): 249-278.

Barnett W. P., \& Hansen M., 1996. “The Red Queen in Organizational Evolution.” Strategic Management Journal, 17(Sp. Iss.): 1996.

Barnett W. P., \& Sorenson, O., 2002. The Red Queen in Organizational Creation and Development. Industrial and Corporate Change, 11(2): 289-325.

Barreto, I. \& Baden-Fuller, C., 2002, Identifying Mimetic Patterns and Measuring Their Consequences among Profit Oriented Firms. Paper presented at the August 2002 Academy of Management annual meeting, Denver, CO.

Baum, J. A. C. \& Korn, H. J., 1996. Competitive Dynamics of Interfirm Rivalry. Academy of Management Journal, 39: 255-291.

Baum, J. A. C. \& Korn, H. J., 1999. Dynamics of Dyadic Competition. Strategic Management Journal, 20: 251-278.

Baum, J. A. C. \& Haveman, H. A., 1997. Love Thy Neighbor? Differentiation and Agglomeration in the Manhattan Hotel Industry, 1989-1990. Administrative Science Quarterly, 42: 304-338. 
Baum, J. A. C, Li, S. X. \& Usher, J. M., 2000. Making the Next Move: How Experiential and Vicarious Learning Shape the Locations of Chains’ Acquisitions. Administrative Science Quarterly, 45:766-801.

Bernheim, B. D. \& Whinston, M. D., 1990. Multimarket Contact and Collusive Behavior. Rand Journal of Economics, 21: 1-26.

Bikhchandani, S., Hirshleifer, D., \& Welch, I., 1992. A Theory of Fads, Fashion, Custom, and Cultural Change as Informational Cascades. Journal of Political Economy, 100: 9921026.

Bikhchandani, S., Hirshleifer, D., \& Welch, I., 1998. Learning from the Behavior of Others: Conformity, Fads, and Informational Cascades. Journal of Economic Perspectives, 12: 151-170.

Bikhchandani, S., \& Sharma, S., 2001. Herd Behavior in Financial Markets: A Review. UCLA working paper.

Boeker, W. J. G., Stephan, J., \& Murmann, J. P., 1997. Competition in a Multimarket Environment: The Case of Market Exit. Organization Science, 8: 126-142.

Burns, L. \& Wholey, D., 1993. Adoption and Abandonment of Matrix Management Programs: Effects of Organizational Characteristics and Interorganizational Networks. Academy of Management Journal, 36: 106-138.

Carroll, G. R. \& M. T. Hannan, 1995. Organizations in Industry: Strategy, Structure and Selection. New York: Oxford University Press.

Caves, R. E., Porter, M. E., Spence, A. M., with Scott, J. T., 1980. Competition in the Open Economy: A Model Applied to Canada. Cambridge, MA: Cambridge University Press.

Chen, M.-J., \& MacMillan, I. C., 1992. Nonresponse, and Delayed Response to Competitive Moves: The Roles of Competitor Dependence and Action Irreversibility. Academy of Management Journal, 35: 539-570.

Chen, M.-J., K. G. Smith, \& C. M. Grimm, 1992. Action Characteristics as Predictors of Competitive Responses. Management Science, 38:439-455.

Cockburn, I. \& Henderson, R., 1994. Racing to Invest? The Dynamics of Competition in Ethical Drug Discovery. Journal of Economics and Management Strategy, 3: 481-519.

Cohen, W. M. \& Levinthal, D. A., 1990. Absorptive Capacity: A New Perspective on Learning and Innovation. Administrative Science Quarterly, 35: 128-152.

Collis, D. J., 1991. A Resource-Based Analysis of Global Competition: The Case of the Bearing Industry. Strategic Management Journal, 12: 49-68.

Cyert, R. M. \& March, J. G., 1963. A Behavioral Theory of the Firm. Englewood Cliffs, N.J.: Prentice-Hall. 
Dasgupta, P. \& Stiglitz, J. E., 1980. Industrial Structure and the Nature of Innovative Activity. Economic Journal, 90: 266-293.

Davis, G. F., 1991. Agents without Principles? The Spread of the Poison Pill through the Intercorporate Network. Administrative Science Quarterly, 38: 583-613.

Davis, G. F., Diekmann, K. A. \& Tinsley, C. H., (1994). The Decline and Fall of the Conglomerate Firm in the 1980s: The Deinstitutionalization of An Organizational Form. American Sociological Review, 59(4): 547-570.

Deephouse, D. L., 1999. To be Different, or to be the Same? It's a Question (and Theory) of Strategic Balance. Strategic Management Journal, 20:147-166.

DiMaggio, P. J. \& Powell, W. W., 1983. The Iron Cage Revisted: Institutional Isomorphism and Collective Rationality in Organization Fields. American Sociological Review, 48: 147160.

Edwards, C. D., 1955. Conglomerate Bigness as a Source of Power in Business Concentration and Price Policy (NBER Conference Report). Princeton, NJ: Princeton University Press.

Evans, W. M. \& Kessides, I. N., 1994. Living by the "Golden Rule": Multimarket Contact in the U.S. Airline Industry. Quarterly Journal of Economics, 109: 341-366.

Fiegenbaum, A. \& Thomas, H., 1995. Strategic Groups as Reference Groups: Theory, Modeling and Empirical Examination of Industry and Competitive Strategy. Strategic Management Journal, 16(6): 461-476.

Fligstein, N., 1985. The Spread of the Multidivisional Form among Large Firms, 1919-1979. American Sociological Review, 50: 377-391.

Fligstein, N., 1991. The Structural Transformation of American Industry: An Institutional Account of the Causes of Diversification in the Largest Firms, 1919-1979. In W.W. Powell \& P. J. DiMaggio, eds., The New Institutionalism in Organization Analysis. Chicago, IL: University of Chicago Press.

Flowers, E. B., 1976. Oligopolistic Reactions in European and Canadian Direct Investment in the United States. Journal of International Business Studies, 7: 43-55.

Garcia-Pont, C. \& N. Nohira, 2002. Local Versus Global Mimetism: The Dynamics of Alliance Formation in the Automobile Industry. Strategic Management Journal, 23: 307-321.

Ghemawat, P., (1991). Commitment: The Dynamics of Strategy. New York: Free Press.

Gilbert, R. J. \& M. B. Lieberman, 1987. Investment and Coordination in Oligopolistic Industries. Rand Journal of Economics, 18: 17-33.

Gimeno, J. \& Chen, M.-J., 1998. The Dynamics of Competitive Positioning: A Pair-wise Perspective. Academy of Management Proceedings, BPS: 01-08. 
Gimeno, J. \& Woo, C. Y., 1996. Hypercompetition in an Multimarket Environment: The Role of Strategic Similarity and Multimarket Contact in Competitive De-escalation. Organization Science, 7: 322-341.

Gimeno, J., Hoskisson, R. E., Beal, B. D., \& Wan, W. P., 2001. Explanations of Clustering in the International Expansion Moves of U.S. Telecommunications Firms. Paper presented at Strategic Management Society meeting, San Francisco, CA.

Granovetter, Mark. 1985. Economic action and social structure: the problem of embeddedness. American Journal of Sociology, 91: 481-510.

Greve, H. R., 1995. Jumping Ship: The Diffusion of Strategy Abandonment. Administrative Science Quarterly, 40: 444-473.

Greve, H. R., 1996. Patterns of Competition: The Diffusion of a Market Position in Radio Broadcasting. Administrative Science Quarterly, 41: 29-60.

Greve, H. R., 1998. Performance, Aspirations and Risky Organizational Change. Administrative Science Quarterly, 43(1): 58-86.

Gulati, R. \& M. Gargiulo. Where Do Organizational Networks Come From? American Journal of Sociology, 104:1439-1493.

Gulati, R., N. Nohria \& A Zaheer, 2000. Strategic Networks. Strategic Management Journal, 21: 203-215.

Hannan, M. T. \& G. R. Carroll, 1992. Dynamics of Organizational Populations: Density, Competition and Legitimation. New York: Oxford University Press.

Haveman, H. A., 1993. Follow the Leader: Mimetic Isomorphism and Entry into New Markets. Administrative Science Quarterly, 38: 593-627.

Haunschild, P. R., 1993. Interorganizational Imitation: The Impact of Interlocks on Corporate Acquisition Activity. Administrative Science Quarterly, 38(4): 564-592.

Haunschild, P. R. \& Miner, A. S., 1997. Modes of Interorganizational Imitations: The Effects of Outcome Salience and Uncertainty. Administrative Science Quarterly, 42(3): 472-500.

Hawley, A. H., 1986. Human Ecology: A Theoretical Essay. Chicago, IL: University of Chicago Press.

Head, K., Mayer, T. and Ries, J., 2002. Revisiting Oligopolistic Reaction: Are Decisions on Foreign Direct Investments Strategic Complements? Journal of Economics and Management Strategy, 11(3): 453-472.

Heggestad, A. A. \& Rhoades, S. A., 1978. Multimarket Interdependence and Local Market Competition in Banking. Review of Economics and Statistics, 60: 523-532. 
Heinsz, W. J. \& A. Delios, 2001. Uncertainty, Imitation, and Plant Location: Japanese Multinational Corporations, 1990-1996. Administrative Science Quarterly, 46: 443475.

Helfat, C., 1997. Know-how and Asset Complementarity and Dynamic Capability Accumulation: The Case of R\&D. Strategic Management Journal, 18(5): 339-360.

Hennart, J.-F. \& Y.-R. Park, 1994. Location, Governance, and Strategic Determinants of Japanese Manufacturing Investment in the United States. Strategic Management Journal, 15: 419-436.

Hirshliefer, D. \& Teoh, S. H., 2001. Herd Behavior and Cascading in Capital Markets: A Review and Synthesis. Working paper, Ohio State University.

Karnani, A. \& Wernerfelt, B., 1985. Multiple Point Competition. Strategic Management Journal, 6: 87-96.

Katz. M. L. \& Shapiro, C., 1985. Network Externalities, Competition, and Compatibility. American Economic Review, 75: 424-440.

Kennedy, R. E., 2002. Strategy Fads and Competitive Convergence: an Empirical Test for Herd Behavior in Prime-Time Television Programming. Journal of Industrial Economics, 50: 43-56.

Klemperer, P., 1992. Equilibrium Product Lines: Competing Head-to-Head May Be Less Competitive. American Economic Review, 82: 740-755.

Knickerbocker, F. T., 1973. Oligopolistic Reaction and Multinational Enterprise. Boston, MA: Harvard Business School.

Knight, F. H., 1921. Risk Uncertainty, and Profit. Boston, MA: Houghton-Mifflin.

Kreps, D. M. \& Spence, A. M., 1985. Modelling the role of history in industrial organization and competition. In G. R. Feiwel, ed., Issues in Contemporary Microeconomics and Welfare. London: Macmillan.

Leahy, D., \& Pavelin, S., 2003. Follow-my-leader FDI and Tacit Collusion. International Journal of Industrial Organization, 21: 439-453.

Leibenstein, H., 1950. Bandwagon, Snob, and Veblen Effects in the Theory of Consumers' Demand. Quarterly Journal of Economics, 64: 183-207.

Levitt, B \& March, J.,1988. Organizational Learning, Annual Review of Sociology, 14: 319-40.

Lieberman, M. B., 2002. Did First-Mover Advantage Survive the Dot-Com Crash? UCLA Working Paper.

Lieberman, M. B., \& Montgomery, D. B., 1988. First-Mover Advantages. Strategic Management Journal, 9: 41-58. 
Lippman, S.A. \& R.P. Rumelt, 1982. Uncertain Imitability: An Analysis of Interfirm Differences in Efficiency under Competition. Bell Journal of Economics, 13(2): 418438.

Lu, J. W., 2002. Intra- and Inter-organizational Imitative Behavior: Institutional Influences on Japanese Firms' Entry Mode Choice. Journal of International Business Studies, 33: 19-37.

Makino, S. \& A. Delios, 2000. Competitive Reaction, Imitation and Bunching in Foreign Entry Decisions. Academy of Management Proceedings, IM: C1-C6.

Manski, C. F., 2000. Economic Analysis of Social Interactions. Journal of Economic Perspectives, 14(3): 115-136.

March, J. G., 1981. Decision in Organizations and Theories of Choice. A.H. Van de Ven and W. F. Joyce eds. Perspectives on Organization Design and Behavior, 205-244, New York: Wiley.

March, J. G. \& Simon, H. A., 1958. Organizations. New York: Wiley.

Martin, X., Swaminathan, A. \& Mitchell, W., 1998. Organizational Evolution in the Interorganizational Environment: Incentives and Contraints on International Expansion Strategy. Administrative Science Quarterly, 43(3): 566-601.

Milliken, F. J., 1987. Three Types of Perceived Uncertainty About the Environment. Academy of Management Review, 12(1): 133-143.

Miner, A. S. \& Haunschild, P. R., 1995. Population Level Learning. Research in Organizational Behavior, 17: 115-166.

Moriguchi, C. and D. Lane, 1999. A Hundred-Year War: Coke vs. Pepsi, 1890s-1990s. Harvard Business School Case 9-799-177.

Motta, M., 1994. International Trade and Investments in a Vertically Differentiated Industry. International Journal of Industrial Organization, 12: 179-196.

Numagami, T., Asaba, S., Shintaku, J., \& Amikura, H., 1992. Taiwa toshiteno Kyoso --Dentaku Sangyo niokeru Kyoso Kodo no Saikaishaku (Competition as Dialogue --Reinterpretation of Competitive Behavior in Electrical Calculator Industry). Soshiki Kagaku (Organizational Science), 26: 64-79 (in Japanese).

Odagiri, H., 1992. Growth through Competition, Competition through Growth. Oxford: Oxford University Press.

Ounjian, M. L., \& Carne, E. B., 1987. A Study of the Factors Which Affect Technology Transfers in a Multilocation Multibusiness Unit Corporation. IEEE Transactions on Engineering Management, EM-34, 194-201. 
Palley, T. I., 1995. Safety in Numbers: A Model of Managerial Herd Behavior. Journal of Economic Behavior and Organization, 28: 443-450.

Peteraf, M. A., 1993. The Cornerstones of Competitive Advantage: A Resource-Based View. Strategic Management Journal, 14: 179-192.

Porter, M. E., 1979. The Structure within Industries and Companies' Performance. Review of Economics and Statistics, 61: 214-227.

Rao, H., Greve, H. R., \& Davis, G. F., 2001. Fool's Gold: Social Proof in the Initiation and Abandonment of Coverage by Wall Street Analysts. Administrative Science Quarterly, 46: 502-526.

Rivkin, J. W., 2000. Imitation of Complex Strategies. Management Science, 46: 824-844.

Rogers, E. M., 1995. Diffusion of Innovations (Fourth Edition). New York: Free Press.

Rosenbloom, R. \& Cusumano, M., 1987. Technological Pioneering and Competitive Advantage: The Birth of the VCR Industry. California Management Review, 29(4): 51-76.

Rosenkopf, L. \& Abrahamson, E. 1999. Modeling Reputation and Information Influences in Threshold Models of Bandwagon Innovation Diffusion. Computational and Mathematical Organizational Theory, 5: 361-384.

Rhoades, S. A. \& Heggestad, A. A., 1985. Multimarket Interdependence and Performance in Banking: Two Tests. The Antitrust Bulletin, 31: 975-995.

Scherer, F. M. (1980). Industrial Market Structure and Economic Performance. Chicago, IL: Rand McNally.

Scharfstein, D. S. \& Stein, J. C., 1990. Herd Behavior and Investment. American Economic Review, 80: 465-479.

Schumpeter, J., 1942. Capitalism, Socialism and Democracy. New York: Harper.

Scott, J. T., 1982. Multimarket Conctact and Economic Performance. Review of Economics and Statistics, 64: 368-375.

Scott, J. T., 1991. Multimarket Contact among Diversified Oligopolists. International Journal of Industrial Organization, 9: 225-238.

Shaver, J. M., Mitchell, W. \& Yeung, B., 1997. The Effect of Own-firm and Other-firm Experience on Foreign Direct Investment Survival in the United States 19981-1992. Strategic Management Journal, 18: 811-824.

Strang, D., \& Tuma, N. B. (1993). Spatial and Temporal Heterogeneity in Diffusion. American Journal of Sociology, 99 (3): 614-639. 
Stuart, T., 1998. Producer network positions and propensities to collaborate: An investigation of strategic alliance formations in a high-technology industry. Administrative Science Quarterly, 43: 668-698.

Szulanski, G., 1996. Exploring Internal Stickiness: Impediments to the Transfer of Best Practice within the Firm. Strategic Management Journal, 17: 27-43.

Teece, D. J., Pisano, G., \& Shuen, A., 1997. Dynamic Capabilities and Strategic Management. Strategic Management Journal, 18: 509-533.

Westphal, J., Gulati, R. and Shortell, S., 1997. Customization or Conformity? An Institutional and Network Perspective on the Content and Consequences of TQM Adoption. Administrative Science Quarterly, 42: 366-394.

White, L., 1971. The Automobile Industry Since 1945. Cambridge, MA: Harvard University Press.

Yamawaki, H., 1998. Bunching in Foreign Direct Investment: Evidence on Japanese Firms in U.S. Manufacturing Industries. CIBER Working Paper No. 98-20. Los Angeles, CA: University of California, Los Angeles, Anderson School of Management.

Yu, C.-M. J. \& Ito, K., 1988. Oligopolistic Reaction and Foreign Direct Investment: The Case of the U.S. Tire and Textile Industries. Journal of International Business Studies, 19: 449-460. 
TABLE 1

\section{Empirical Studies of Imitative Behavior}

\begin{tabular}{|c|c|c|}
\hline TOPIC AREA AND STUDY & PHENOMENA/INDUSTRY & KEY FINDINGS \\
\hline \multicolumn{3}{|l|}{$\begin{array}{l}\text { Multimarket contact to mitigate } \\
\text { competition }\end{array}$} \\
\hline Heggestad \& Rhodes (1978) & Banks & Multimarket contact stabilizes dominant firms' market share. \\
\hline Rhodes \& Heggestad (1985) & Banks & "Mutual forbearance" is not confirmed. \\
\hline Scott $(1982,1991)$ & Diversification & Multimarket contact is associated with higher profits in highly concentrated industries. \\
\hline Evans \& Kessides (1994) & Airlines & Major airlines set higher fares on routes where average levels of multimarket contact are higher. \\
\hline Baum \& Korn (1996) & California commuter airlines (1979-1984) & Lower likelihood of exit for firms having greater multimarket contact with market incumbents. \\
\hline Gimeno \& Woo (1996) & Airlines & Multimarket contact decreases the intensity of competition. \\
\hline Boeker et al. (1997) & California hospitals 1980-1986 & Multimarket competition lowers the rate of exit. \\
\hline Baum \& Korn (1999) & California commuter airlines (1979-1984) & Effects of multimarket competition vary across competitor dyads. \\
\hline \multicolumn{3}{|c|}{ Investment bunching as risk-reduction } \\
\hline Knickerbocker (1973) & FDI by US firms & Bunching behavior is more likely to occur in moderately concentrated industries. \\
\hline Flowers (1976) & FDI in the US by Canadian and European firms & Bunching of entry is positively related with home market concentration. \\
\hline Caves, Porter, \& Spence (1980) & FDI in Canada by US firms & Bunching of entry is positively related with home market concentration. \\
\hline Yu \& Ito (1988) & FDI by US tire and textile firms & Bunching of entry is positively related with home market concentration. \\
\hline Kogut \& Chang (1991) & FDI in the US by Japanese firms & Bunching of entry is positively related with home market concentration. \\
\hline Hennart \& Park (1994) & FDI in the US by Japanese firms & Positive relation between bunching behavior and market concentration is not confirmed. \\
\hline Yamawaki (1998) & FDI in the US by Japanese firms & Bunching of entry is positively related with home market concentration. \\
\hline Makino \& Delios (2000) & FDI by Japanese auto and electronic companies & Strong bunching effect in timing of FDI is observed. \\
\hline Chen \& MacMillan (1992) & Action-Response by airlines & A firm is more likely to match a move with its dependence on the market. \\
\hline Cockburn \& Henderson (1994) & R\&D by pharmaceutical firms & R\&D expenditures among firms are weakly and positively correlated. \\
\hline Haunschild (1993) & Acquisitions during the $1981-1990$ period. & Managers imitate the acquisition activities of those other firms to which they are tied via directorships. \\
\hline
\end{tabular}




\begin{tabular}{|c|c|c|}
\hline Haveman (1993) & Entry in savings and loan industry & Rate of entry has inverted U-shaped relationship with density (competition- vs legitimation+). \\
\hline Greve (1995; 1996) & Adoption of new formats by radio stations & Radio stations imitate stations of the same corporation. \\
\hline Haunshild \& Miner (1997) & Investment banker chosen for acquisitions & Imitation influenced by frequency of observed behavior, traits of imitated firms and quality of outcome. \\
\hline Westphal et al. (1997) & Implementation of TQM (total quality mgmt) & Earlier adopters seek efficiency gains, while later adopters seek legitimacy. \\
\hline Baum \& Haveman (1997) & Hotel location decisions in Manhattan & New hotels locate close to established hotels that are similar in price, but different in size. \\
\hline Deephouse (1999) & Performance and strategic similarity among banks & Intermediate levels of strategic similarity lead to the highest performance. \\
\hline Baum et al. (2000) & Acquisition of chain organizations (nursing homes) & Chain organizations imitate comparable others (similar sized chains). \\
\hline Henisz \& Delios (2001) & International plant location & Prior decisions by others provide legitimization and information. \\
\hline Lu (2002) & Entry mode choice of Japanese firms & Later entrants tend to follow the entry mode of earlier entrants. \\
\hline Garcia-pont \& Nohira (2002) & Alliance formation in the automobile industry & Firms imitate the strategic behavior of others occupying the same strategic niche. \\
\hline \multicolumn{3}{|l|}{ Herd behavior (economics) } \\
\hline Chang et al. (1997) & Clustering of bank branches & Branch openings follow other, existing branches. \\
\hline Kennedy (2002) & Prime television programming & Television networks introduce new programs in herd-like fashion. \\
\hline Rao et al. (2001) & Choice of securities analysts & Analysts change coverage of a firm when peers have recently changed coverage \\
\hline \multicolumn{3}{|c|}{ Studies testing among alternative theories } \\
\hline Gilbert \& Lieberman (1987) & Capacity investment by chemical firms & Smaller firms tend to follow investment behavior of larger rivals. \\
\hline Gimeno \& Chen (1998) & Market similarity in the airline industry & Firms increase market similarity with rivals having similar resources and higher performance. \\
\hline Asaba \& Lieberman (1999) & Product introduction by soft drink firms & Large firms followed for major innovations; rivals followed for minor innovations. \\
\hline Gimeno et al. (2001) & International expansion of telecom firms & Oligopolistic firms imitate each other's local entry moves, while local monopolists do not. \\
\hline
\end{tabular}




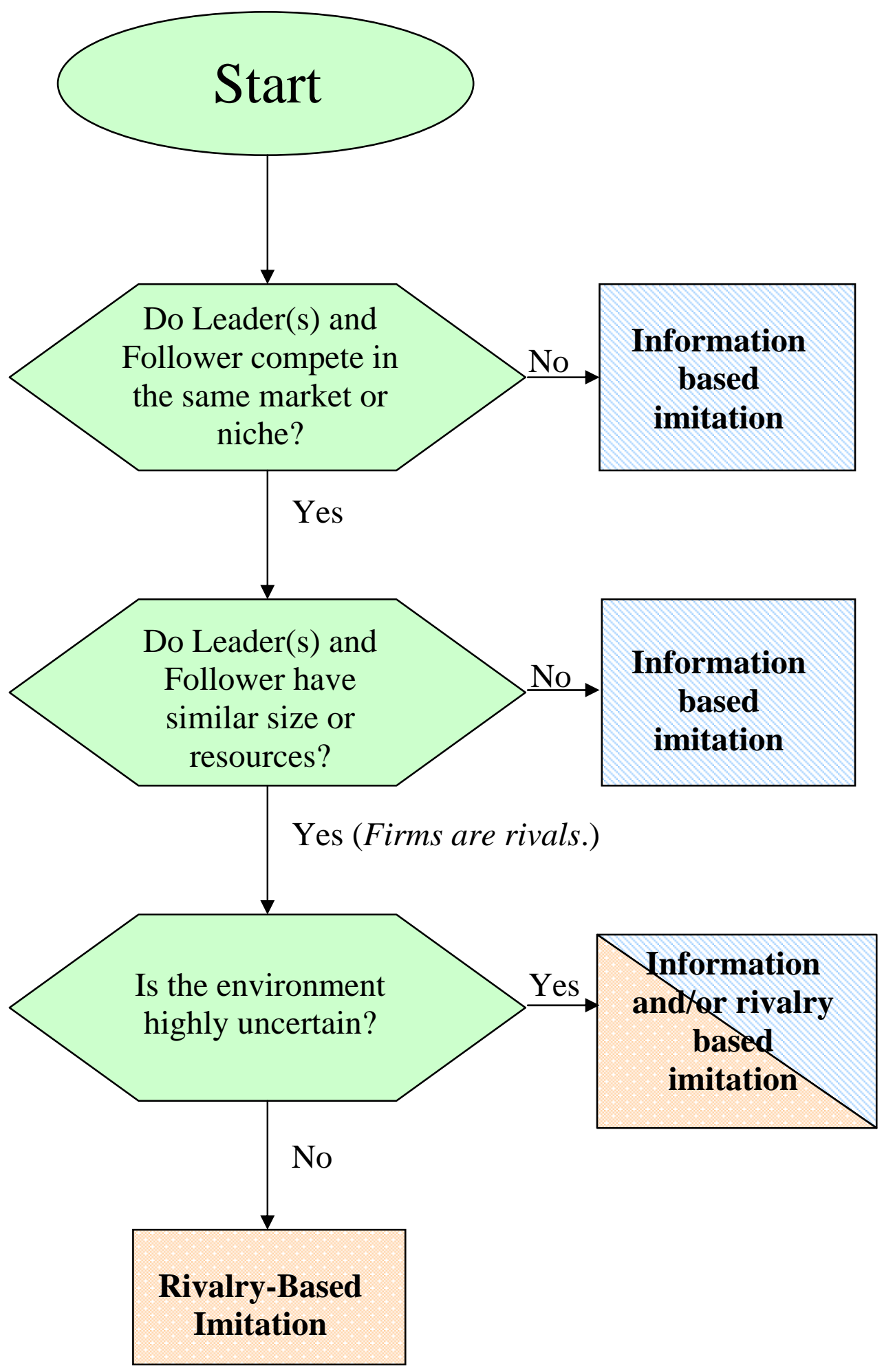

Figure 1. Conditions to distinguish between information-based and rivalry-based imitation. 